\title{
ESTIMATION OF PRICE AND INCOME ELASTICITY OF DEMAND FOR MILK IN SLOVAKIA
}

\author{
Lucia Vargová ${ }^{147}$ \\ Martin Jamrich ${ }^{148}$
}

https://doi.org/10.31410/itema.2018.357

\begin{abstract}
Despite the fact that situation has changed significantly in recent years and the share of milk production in the total agriculture production tends to decline, milk still represents a significant part of the food products in Slovak households. The study presents the important data on dairy sector balances, focuses on prices and income elasticity. Using dataset from the Household Budget Survey of Slovakia, we estimated the price elasticity of demand for skimmed and whole milk. Due to the nature of data, we used the Cragg's double hurdle model for estimation, in the time period from 2006 to 2012. The results show that the demand for whole milk is elastic (1.42) and for skimmed milk is inelastic (0.53). The rise in prices of whole milk causes an increase in the consumption of skimmed milk by $0.30 \%$ and higher prices of skimmed milk leads to increasing of demand for whole milk by $0.37 \%$, therefore they are substitutes. The influence of other dairy products such as a dried milk, yoghurt, cheese is mainly either insignificant (whole milk) or very low (skimmed milk). The income factor positively influences the consumption of milk and leads to a small increase in the consumption of skimmed milk what suggest that both type of milk are normal goods.
\end{abstract}

Keywords: demand for milk, price elasticity, income elasticity, double-hurdle model

\section{INTRODUCTION}

$\mathrm{M}$ ilk belongs to the staple food products and it is also a crucial commodity among the European Union states. It is produced in every single EU country and generally, the dairy sector contributes to $12.2 \%$ of the total agricultural output, right after vegetables and horticultural plants (13.2\%). In Slovakia, the milk production represents just about 13.5\% of total agriculture production (Eurostat, 2017). Despite the fact that this percentage share has been declining over the past years, dairy production has a significant position in the economy. The other words, it has an impact on the welfare of the economy as a whole and it affects both ends of the food supply chain, i.e. producers and consumers (households). The effect on consumers also depends on price volatility and the extent to which retail prices react to producer prices (Gilbert and Morgan, 2010). Garcia-German (2014) states that higher volatility in retail prices has a greater influence on the consumers who spend a larger scale of their income on food.

The agriculture economists have started to focus their attention on the analysis of the pricing market structure and consumption of households. Many recent studies also have concentrated on marketing activities influencing the demand for dairy products and paid attention to factors affecting demand and market prices. Socio-demographic effects, such as the age and gender of the consumers, household size, the composition of household members, level of monthly

\footnotetext{
${ }^{147}$ Department of Economic Policy, FEM SUA Nitra, Tr. A. Hlinku 2, 94976 Nitra, Slovakia

${ }^{148}$ Department of Economic Policy, FEM SUA Nitra, Tr. A. Hlinku 2, 94976 Nitra, Slovakia
} 
income, health problems effect, urbanization, ethnicity, the region of residence, seasonality etc. (Heien and Wessells 1988; Gould, 1996; Hatirli, et. al., 2004; Goktolga et. Al. 2006; De Alwis, et.al., 2011; Denver and Jensen, 2014) have been identified as household characteristics representing the important role in consumption and in the purchasing behavior. Dong et. al. (2004) examined fluid milk purchasing behavior with panel data from New York households, using a Double-hurdle model. From the empirical testing was found that the prices are inelastic and generic dairy advertising increases the probability of market participation and simultaneously purchase quantity and incidence. Davis et. al. (2009) examined demand elasticity for fluid milk products in the United States, using a censored translog demand system and the results showed that price and income are the main determinants of the demand for dairy products. Alviola and Capps (2010) used the probit model to find out the impact of the selected demographic variables connected with the purchase of organic fluid milk. They ascertained that factors like earnings and education have a significant position in the household choice of purchasing organic milk. Tiryaki and Akbay (2009) used the multinomial logit procedure to study selected socioeconomic and demographic aspects of consumers that determine households' fluid milk consumption. The results concluded that as the earnings grow then household tends more to consume processed milk rather than buying unprocessed milk. The effect of income was found as the highest on the probability of consuming processed milk. Bai et al. (2008) adopted a Tobit model to estimate the influences of socio-demographic characteristics of urban consumers on their fluid milk consumption in Qingdao in China. The major results showed that fluid milk consumption in urban Qingdao is much higher compared to China's national level and also income has the positive influence on milk consumption.

The objective of the paper is to estimate price elasticity of demand for skimmed and whole milk in Slovakia. Using the household dataset from the Household Budget Survey, we focus on the time period of 2006-2012. The paper is organized in the following parts - the next section describes the Slovak dairy sector, its current changes in the market structure, productivity, consumption and trade in Slovakia. The second part provides a description of the theoretical model used to test the elasticity of demand, and summaries the data and variables used in the econometric analyses. In the third part, the estimations of tests are presented and the final part summarizes the results and conclusions.

\subsection{MARKET STRUCTURE OF DAIRY SECTOR IN SLOVAKIA}

Slovak agriculture has differed strongly from the other European Union countries, largely within its farm structure (Swinnen, at al., 2006). Dairy sector has undergone rapid structural changes in the past decade and the number of farms plummeted by more than $35 \%$, mainly due to the low purchase prices. It was one the reasons of the milk crisis in 2008-2009, 2012, and in 2015-16. Just during the last 3 years, the number has dropped from 483 registered dairy farms in 2015 to only 424 in the September 2018 (12\% reduction).

In 2016, milk production of Slovakia reached 933.3 million $\mathrm{kg}$ which represents a decrease by $2.5 \%$ over the previous year and 163 million tones of cow's milk was produced within the EU. Compared to these countries, Slovakia is just a small dairy producer and the production accounted for just $0.5 \%$ share of EU milk deliveries. The majority of Slovak milk is produced on the farms. They are run as cooperatives or private enterprises (limited company or trading companies) and most of the milk is used for processing by buyers. During the observed period, delivery on production was on average about $89 \%$ (see Figure 1). Forty dairy companies and organizations operated with direct milk collection from the agricultural holdings and just 10 of them operated with own-milk processing. 
Figure 1 Cow's milk production, milk deliveries, drinking milk

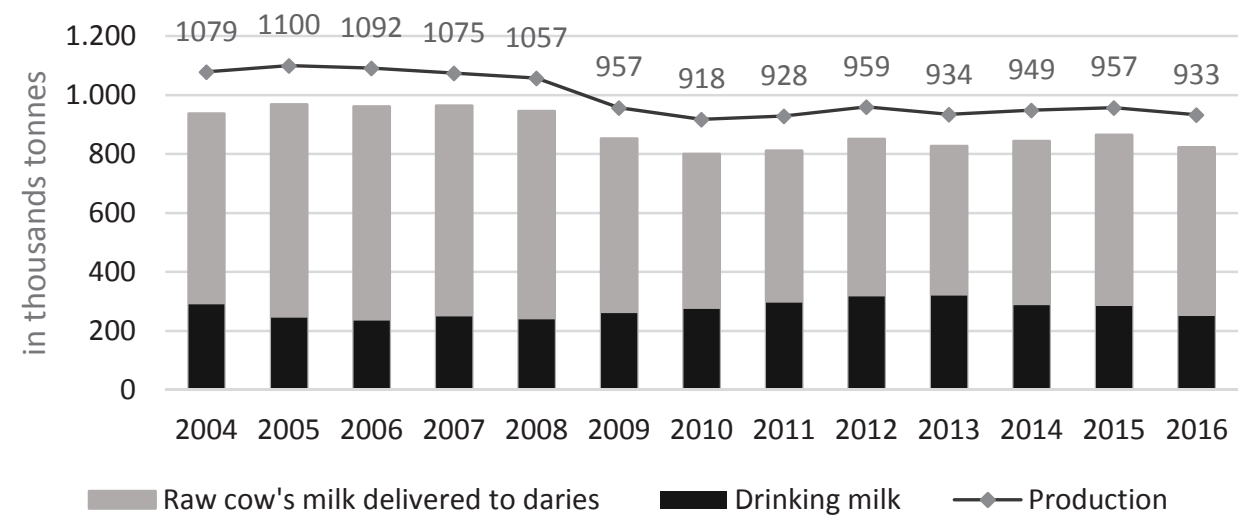

Source: Eurostat

In 2016, 822.7 thousand tones of the cow's raw milk available in the dairy sector was processed into a lot of fresh and manufactured products. $30.5 \%$ of processed milk was used as drinking milk including raw milk, whole milk, semi-skimmed and skimmed milk without any additives and relates only to milk directly intended for consumption. The rest of the milk was used for the proceeding of other dairy products (Eurostat, 2018).

Figure 2 Number of dairy cows (left axis), milk yield (right axis)

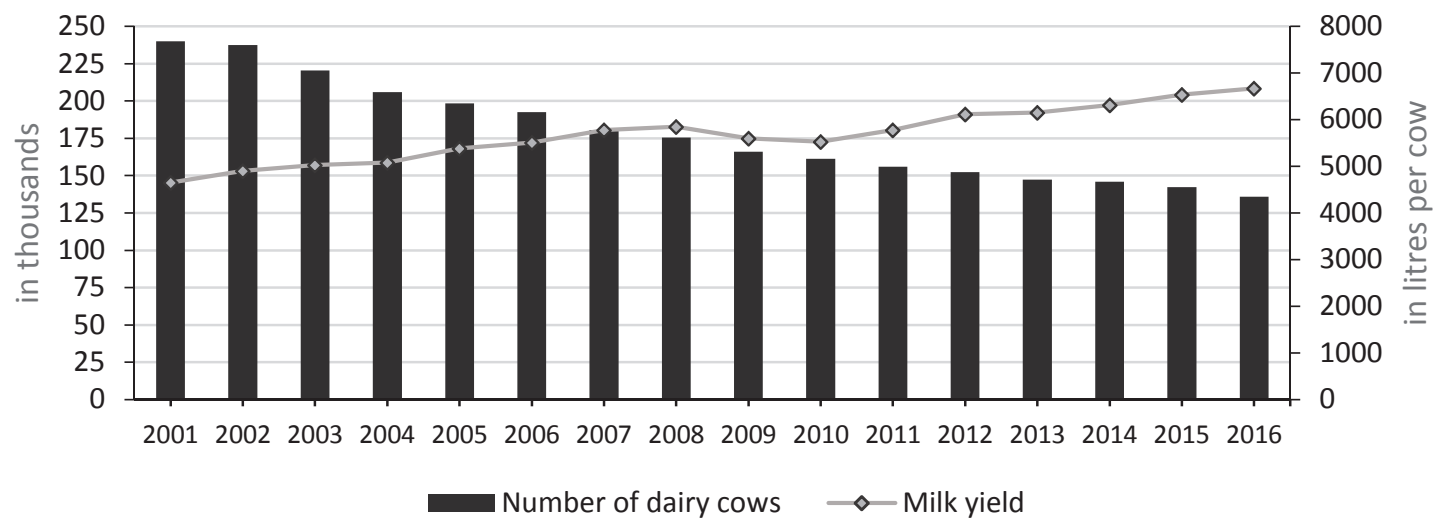

Source: Research Institute of Agriculture and Food Economics

Figure 2 shows the number of dairy cows and milk yields between the years 2001-2016. Since 2006, the average number of dairy cows in the farms decreased by almost $42 \%$ (from 192.5 thousand to 135.9 thousand) and compared to 2001 , by more than three-quarters. Unlike the sharp decrease in dairy cows, average milk yields rose by $21 \%$ since 2006 and compared to the year 2001 , by $43.3 \%$.

A lot of consumers have been changing their purchasing habits in accordance with the nascent 'healthy trends'. This is also one of the factors affecting milk consumption. According to the dairy report of Euromonitor (2017), the main consequences of these trends are increased shares of product innovations based for instance on full-fat fresh milk and other milk alternatives such as soy drinks, goat milk, lactose-free drinking milk products or organic brands. In 2016 the annual consumption of cow's milk amounted to $173.6 \mathrm{~kg}$ per capita and compared to 2006 it 
increased by $15.5 \%$. However, this amount still represents just nearly $80 \%$ of the recommended level (220 kg per year).

In 2017, Slovak export of milk and milk products accounted for just $0.7 \%$ of EU dairy export. The increase in exports and imports would stem from the entry of Slovakia into EU in 2004. Since then a substantially larger part of the raw milk and milk products has been bought directly by foreign companies. Dairy products, converted into milk equivalent, were exported abroad as a share $63.5 \%$ (the year 2017) and 58.1\% (the year 2016) from the milk deliveries.

Figure 3 Foreign trade of milk

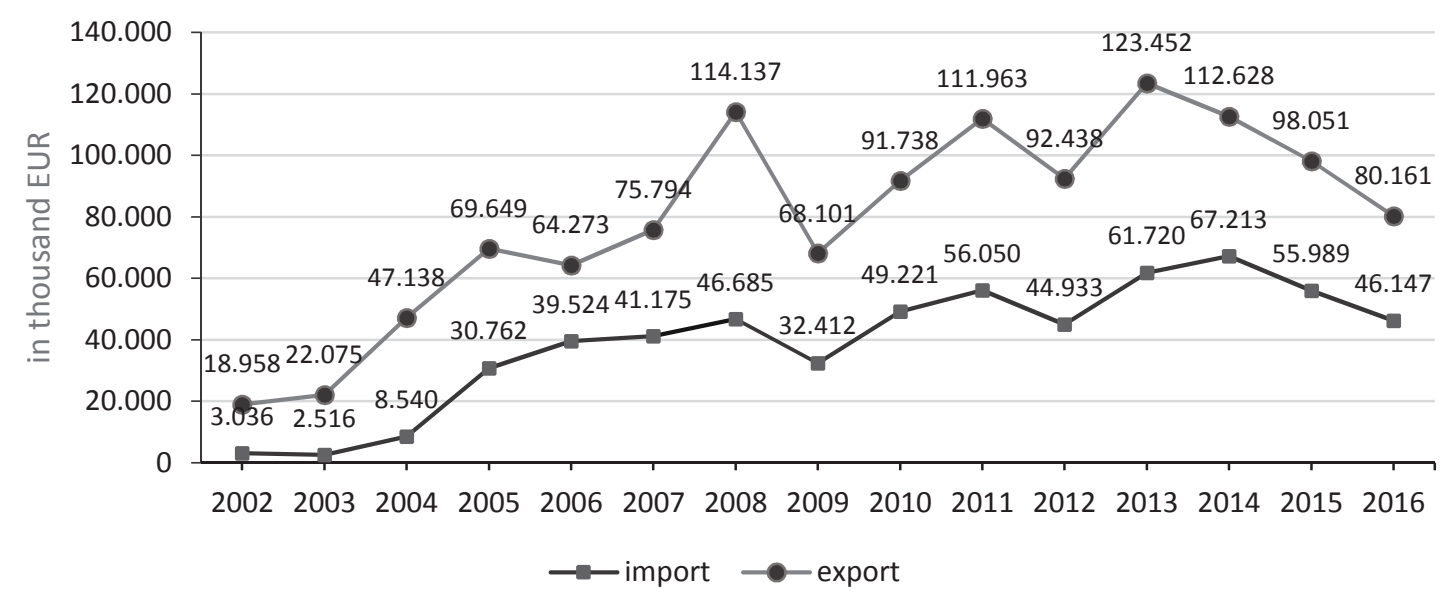

Source: Research Institute of Agriculture and Food Economics

In 2007, the export sales grew rapidly and reached more than 114 million EUR. In 2016, Slovakia exported milk and milk products amounting to 80.1 million EUR (Figure 3). Bulk and packed milk represented 187 thousand tones and $99 \%$ of this amount went to the other European Union countries (intra-trade). The main business partners for export of bulk milk were Germany and Italy, for packed milk Hungary and for other dairy products the Czech Republic (cheese, whey, cream) or Spain (yoghurt and buttermilk). In the same year, milk products were imported to Slovakia amounting to 46 million EUR, which constituted 234.3 thousand tones of dairy products. The main importers were the Czech Republic (packed and bulk milk, cream, yoghurt, buttermilk), Poland (cheese), Romania (whey) and Germany (butter, skimmed milk powder).

\section{DATA AND METHODOLOGY}

The aim of this paper is to estimate price elasticity of demand for skimmed and whole milk in Slovakia. We used data from the Household Budget Survey of Slovakia for period 2006 - 2012 and due to the nature of the dataset, the Cragg's double hurdle model was applied to measure the elasticity.

The month consumption of whole/skimmed milk per household was used as the main dependent variable entering the model. To estimate the price elasticity was essential to determine prices of these products because the dataset did not contain this information. By following Sousa (2014), the prices were derived from expenditures and quantities of consumed milk and simultaneously showed differences of each household. For households with zero consumption, we calculated the average prices of 8 regions by years and quarters, and missing prices were substituted with new estimated prices which were also used as the main explanatory variables. 
Besides the whole and skimmed milk prices, the prices of dried milk, yoghurt, cheese, and other dairy products were also included in the model.

Models contained variables representing household characteristics or time trend. Selection of variables was based on studies focus on the demand for dairy products, e. g. Heien and Wessells (1988); Dong et al. (2007); Bouamra-Mechemache, et al. (2008). Table 1 shows the list of all variables used in the model.

Table 1: Variables entering models

\begin{tabular}{|c|c|}
\hline Dependent variables $\left(Y_{j}\right)$ & Definiton \\
\hline ln_c_milk_whole & log monthly consumption per household (1) \\
\hline ln_c_milk_skim & log monthly consumption per household (1) \\
\hline Instruments $\left(Z_{j}\right)$ & Definiton \\
\hline ln_income & log monthly income per household (EUR) \\
\hline d_whole & $\begin{array}{l}\text { dummy variable for consumption of whole milk, } 1- \\
\text { positive amount of consumption, otherwise } 0\end{array}$ \\
\hline d_skim & $\begin{array}{l}\text { dummy variable for consumption of skim milk, } 1 \text { - positive } \\
\text { amount of consumption, otherwise } 0\end{array}$ \\
\hline Explanatory variables $\left(X_{j}\right)$ & $\begin{array}{rr}\text { Definiton } \\
\end{array}$ \\
\hline ln_p_milk_whole & $\log$ price of whole milk per 1 \\
\hline ln_p_milk_skim & log price of skim milk per 1 \\
\hline ln_p_milk_dried & log price of dry milk per 1 \\
\hline ln_p_yogurt & $\log$ price of yogurt per $100 \mathrm{~g}$ \\
\hline ln_p_cheese & $\log$ price of cheese per $100 \mathrm{~g}$ \\
\hline ln_p_other_dairy & log price of other dairy products 100 per $g$ \\
\hline ln_p_coffee & $\log$ price of coffee per $100 \mathrm{~g}$ \\
\hline $\ln \_p \_$tea & $\log$ price of tea per $100 \mathrm{~g}$ \\
\hline ln_p_cocoa & $\log$ price of coca per $100 \mathrm{~g}$ \\
\hline ln_income & log monthly income per household \\
\hline age_hh & age of head of household \\
\hline male_hh & $\begin{array}{l}\text { dummy variable, gender of head of household, } 1-\text { man, } 0- \\
\text { woman }\end{array}$ \\
\hline employed_hh & $\begin{array}{l}\text { dummy variable for work status of head of household, } 1- \\
\text { employed, } 0 \text { - unemployed or economically inactive person }\end{array}$ \\
\hline n_members & number of members of household \\
\hline sp_household & dummy variable, 1 - single person household, otherwise 0 \\
\hline n_retirees & number of retirees in household \\
\hline n_teenegers & number of teenagers in household (age $13-18$ ) \\
\hline n_children & number of children in household (age < 12) \\
\hline region & dummy variables for 8 regions of Slovakia \\
\hline year & time trend for period $2006-2012$ \\
\hline
\end{tabular}

Source: HBS, own processing

The problem of the censoring shows particularly in the studies using microeconomic data. The database used in this study contains a significant number of households with zero expenditure on milk. It might be caused by several reasons: the period of research is short; households never buy milk or households never buy milk at the given prices or income. 
Estimation of demand by OLS at these circumstances would lead to biased and inconsistent results (Amemiya, 1984). Studies analyzing the demand for food, e.g. Gao et al. (1995), Burton et al. (1996), Yen and Jones (1997), Sharpe et al. (2001), Newman et al. (2003), Mabiso et al. (2005), Mutlu and Gracia (2006), Zhang et al. (2008), Wan and Hu (2012) Eakins, 2016 or Cupak et al. (2016), often use the Cragg's double hurdle model (Cragg, 1971).

The double-hurdle model is appropriate to use if consumers make decisions in two steps hurdles: participation and consumption decision. The first hurdle is estimated by Probit model and the second one with a truncated Tobit model. The participation step is described by equations

$$
\begin{gathered}
d_{j}^{*}=z_{j} \gamma_{j}+u_{j} \\
d_{j}= \begin{cases}1 & \text { if } d_{j}^{*}>0 \\
0 & \text { if } d_{j}^{*} \leq 0\end{cases}
\end{gathered}
$$

where $d_{j}^{*}$ represents unobserved latent variable and $d_{j}$ is observed binary variable. The second step - how much household consume is described by equations

$$
\begin{aligned}
& y_{j}^{*}=x_{j} \beta+v_{j} \quad v_{j} \sim N\left(0, \sigma^{2}\right) \\
& y_{j}=\left\{\begin{array}{c}
y_{j}^{*} \text { if } d_{j}=1 \text { and } y_{j}^{*}>0 \\
0 \text { else }
\end{array}\right.
\end{aligned}
$$

where $y_{j}^{*}$ is unobserved latent variable and $y_{j}$ is actual expenditure on milk which is equal to $y_{j}^{*}$ only in the case that this latent variable takes positive values and participation step is equal to 1. Explanatory variables that determine participation and expenditure hurdles are label as $Z_{j}$ and $x_{j}$. Estimation of coefficients is made by maximum likelihood function.

The means and standard deviations of regression variables for the full sample, for households with positive consumption of whole milk, and for households with positive skimmed milk consumption are presented in Table 2. Average Slovak household has 2.82 members from which 0.34 consists of retirees, 0.21 teenagers (13 - 18 years old) and 0.35 children younger than 13 years.

Average monthly income is 1098 EUR for the full sample, for households consuming skimmed milk it is by 5 EUR more and for households consuming whole milk by almost 100 EUR more. Average consumption is 1.61 liters of whole milk with an average price of 0.70 EUR per liter and 11.92 liters of skimmed milk with an average price of 0.58 EUR per liter. Households with positive consumption of whole milk usually consume 9.69 liters of whole milk per month and 7.07 liters of skimmed milk. On the other hand, households with positive consumption of skimmed milk consume 13.26 liters per month of this kind of milk and 3.92 liters of whole milk. Average prices of other dairy products like yoghurt, cheese, and prices of tea, coffee, and cocoa are also displayed in Table 2. 
Table 2: Summary statistics

\begin{tabular}{|l|cc|cc|cc|}
\hline \multicolumn{1}{|c|}{ Variable } & Full sample & \multicolumn{2}{c|}{$\begin{array}{c}\text { Sample with positive } \\
\text { whole milk } \\
\text { consumption }\end{array}$} & \multicolumn{2}{c|}{$\begin{array}{c}\text { Sample with positive } \\
\text { skim milk } \\
\text { consumption }\end{array}$} \\
& Mean & Std. Dev. & Mean & Std. Dev. & Mean & Std. Dev. \\
\hline c_milk_whole & 1.61 & 5.62 & 9.69 & 10.54 & 0.90 & 3.92 \\
c_milk_skim & 11.92 & 11.93 & 7.04 & 9.33 & 13.26 & 10.78 \\
income & 1098 & 743 & 1192 & 719 & 1103 & 744 \\
p_milk_whole & 0.70 & 0.11 & 0.70 & 0.19 & 0.70 & 0.10 \\
p_milk_skim & 0.58 & 0.10 & 0.58 & 0.10 & 0.58 & 0.10 \\
p_milk_dried & 0.70 & 0.21 & 0.72 & 0.24 & 0.70 & 0.21 \\
p_yogurt & 0.26 & 1.45 & 0.26 & 0.07 & 0.26 & 1.53 \\
p_cheese & 0.57 & 0.12 & 0.58 & 0.12 & 0.57 & 0.12 \\
p_other_dairy & 0.26 & 1.39 & 0.25 & 0.10 & 0.25 & 1.46 \\
p_coffee & 1.49 & 9.27 & 1.47 & 0.94 & 1.49 & 9.77 \\
p_tea & 0.56 & 1.02 & 0.60 & 1.09 & 0.57 & 1.03 \\
p_cocoa & 0.61 & 0.15 & 0.62 & 0.16 & 0.60 & 0.15 \\
age_hh & 51.8 & 14.61 & 51.2 & 14.57 & 51.81 & 14.50 \\
male_hh & 0.68 & 0.47 & 0.72 & 0.45 & 0.68 & 0.47 \\
employed_hh & 0.64 & 0.48 & 0.67 & 0.47 & 0.65 & 0.48 \\
n_members & 2.82 & 1.43 & 3.02 & 1.45 & 2.86 & 1.42 \\
sp_household & 0.22 & 0.41 & 0.16 & 0.37 & 0.20 & 0.40 \\
n_retirees & 0.34 & 0.61 & 0.35 & 0.63 & 0.34 & 0.61 \\
n_teenegers & 0.21 & 0.51 & 0.22 & 0.53 & 0.22 & 0.51 \\
n_children & 0.35 & 0.69 & 0.42 & 0.74 & 0.35 & 0.69 \\
\hline
\end{tabular}

Source: HBS, authors' calculations

\section{RESULTS}

From 2006, consumption of skimmed milk had a declining trend (Figure 4). In 2006, the average consumption of skimmed milk per household constituted 12.6 liters and six years later it decreased by almost 2 liters. However, consumption of whole milk increased during the observed period by $37.6 \%$ and from 2007 had the stable rising trend. Consumer prices of both kinds of milk show a similar volatile pattern. After the reaching maximum in 2008, prices declined sharply and from 2009 increased gradually till 2012.

Figure 4: Price and consumption of whole and skim milk

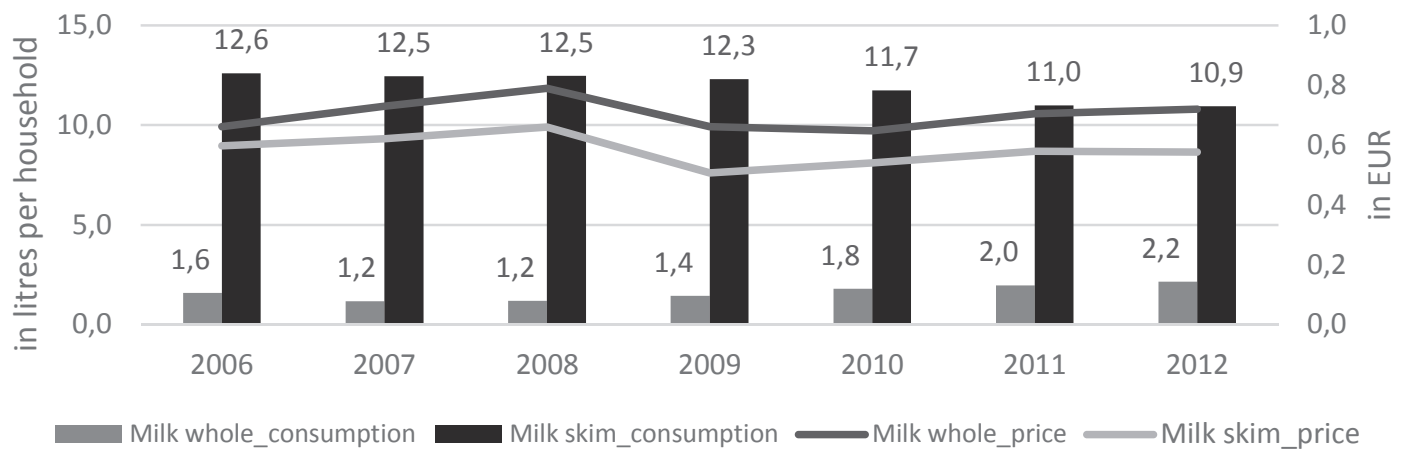

Source: HBS, author's calculations 
Table 3 represents the estimated double-hurdle model for whole and skimmed milk. Whole milk is own price elastic, $1 \%$ increase in the price causes $1.4 \%$ decrease in consumption, in comparison with skimmed milk $(0.5 \%$ decrease in consumption caused by $1 \%$ increase in price) that is price inelastic. The cross-price elasticity indicates that whole and skimmed milk are substitutes. An increase in whole milk prices causes an increase in the consumption of skimmed milk by $0.30 \%$ and in the case of the rising price of skimmed milk it is by $0.37 \%$. Influence of prices of dried milk, yogurt, cheese, and other dairy products is mainly either insignificant (whole milk) or very low (skimmed milk). The same applies to the prices of coffee, tea or cocoa.

The coefficient of income elasticity is significant for skimmed milk but not significant for whole milk. Its value 0.12 indicates that it is a normal good, therefore an increase of income leads to a very small increase in the consumption of skimmed milk. With the rising number of household members obviously rises consumption of milk. The grow of consumption is caused mainly by children, teenagers, and retirees.

Table 3: Estimation of DH model for whole and skim milk

\begin{tabular}{|c|c|c|c|c|}
\hline \multirow{2}{*}{ Variable } & \multicolumn{2}{|c|}{ Milk whole } & \multicolumn{2}{|c|}{ Milk skim } \\
\hline & Coef. & Std. Err. & Coef. & Std. Err. \\
\hline ln_p_milk_skim & $.3674 * * *$ & .0965 & $-.5257 * * *$ & .0291 \\
\hline ln_p_milk_whole & $-1.415 * * *$ & .0696 & $.3032 * * *$ & .0376 \\
\hline ln_p_milk_dried & .0181 & .0471 & $-.0496 * * *$ & .0165 \\
\hline ln_p_yogurt & $.1514 * *$ & .0704 & $.0588 * *$ & .0230 \\
\hline ln_p_cheese & .0210 & .0736 & $-.0863 * * *$ & .0239 \\
\hline ln_p_other_dairy & .0396 & .0394 & -.0181 & .0133 \\
\hline ln_p_coffee & .0352 & .0299 & $.0446 * * *$ & .0096 \\
\hline $\operatorname{ln\_ p\_ tea}$ & -.0156 & .0168 & $-.0207 * * *$ & .0055 \\
\hline $\ln \_$p_cocoa & -.0026 & .0654 & $-.1164 * * *$ & .0225 \\
\hline ln_income & .0247 & .0374 & $.1230 * * *$ & .0123 \\
\hline age_hh & $.0049 * * *$ & .0016 & $.0036 * * *$ & .0005 \\
\hline male_hh & $.0703 *$ & .0369 & .0106 & .0114 \\
\hline employed_hh & $.0805^{*}$ & .0447 & $-.0668 * * *$ & .0145 \\
\hline n_members & $.1191 * * *$ & .0184 & $.1627 * * *$ & .0063 \\
\hline sp_household & $-.1247 * *$ & .0587 & $-.2049 * * *$ & .0171 \\
\hline n_retirees & $.0751 * *$ & .0297 & $.0299 * * *$ & .0100 \\
\hline $\mathrm{n}$ _teenegers & .0047 & .0315 & $.0422 * * *$ & .0107 \\
\hline n_children & $.1127 * * *$ & .0263 & $.1111 * * *$ & .0091 \\
\hline $\mathrm{TT}$ & .0419 & .0682 & $.1456 * * *$ & .0192 \\
\hline $\mathrm{TN}$ & $.1518 * *$ & .0567 & $.0786 * * *$ & .0187 \\
\hline NR & .0399 & .0626 & $.1082 * * *$ & .0187 \\
\hline $\mathrm{ZA}$ & $.1003 *$ & .0553 & .0183 & .0189 \\
\hline $\mathrm{BB}$ & .0560 & .0612 & $.0627 * * *$ & .0199 \\
\hline PO & $.1935 * * *$ & .0629 & $.0797 * * *$ & .0202 \\
\hline $\mathrm{KE}$ & .0596 & .0619 & -.0274 & .0190 \\
\hline year & $-.0267 * * *$ & .0085 & $-.0278 * * *$ & .0027 \\
\hline _cons & 54.60 & 17.19 & $56.39 * * *$ & 5.588 \\
\hline selection 11 & & & & \\
\hline ln_income & $.2404 * * *$ & .0170 & $.2065 * * *$ & .0173 \\
\hline d_skim & $-1.381 * * *$ & .0272 & - & - \\
\hline
\end{tabular}




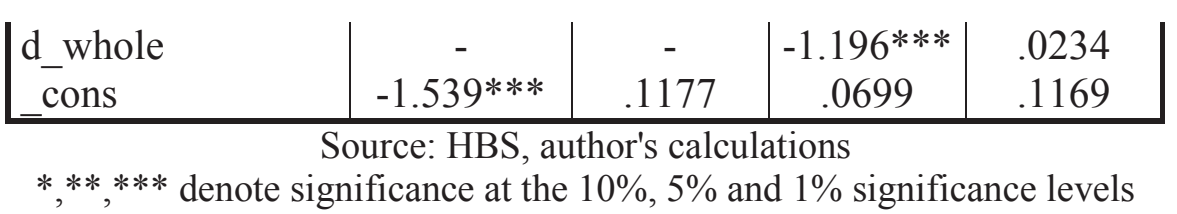

The latest part of Table 3 contains the effect of income and dummy variables for skimmed and whole milk. All parameters are statistically highly significant. Income positively influences the decision to consume milk and dummy variable d_skim in the model for whole milk has negative value, which means the consumption of skimmed milk by the household has a negative effect on the decision to consume whole milk and vice versa.

\section{CONCLUSION}

The study employed the econometric techniques to analyze the price and income elasticity for whole and skimmed milk in Slovakia. The Household Budget Survey data were used in order to build the Cragg's double hurdle model for the time period from 2006 to 2012. To estimate the price elasticity, prices were derived from expenditures and quantities of consumed milk per household. The empirical results show that households are more likely to buy skimmed milk. Demand for skimmed milk was shown as inelastic and for whole milk as elastic. Findings also implied that the observed dairy products are substitutes because an increase of whole milk prices leads to the increase in the consumption of skimmed milk and vice versa. The number of household members, mainly children, teenagers and retirees, affects the consumption of milk and the income is considered as another factor that positively influences the amount of consumed milk.

\section{ACKNOWLEDGEMENTS}

This work was supported by the Slovak Research and Development Agency under the contract No. APVV-15-0552.

\section{REFERENCES}

[1] Amemiya, T. (1984). Tobit models: A survey. Journal of econometrics, 24(1-2), 3-61.

[2] Alviola IV, P. A., Capps Jr, O. (2010). Household demand analysis of organic and conventional fluid milk in the United States based on the 2004 Nielsen Homescan panel. Agribusiness, 26(3), 369-388.

[3] Bai, J., Wahl, T. I., McCluskey, J. J. (2008). Fluid milk consumption in urban Qingdao, China. Australian Journal of Agricultural and Resource Economics, 52(2), 133-147.

[4] Bouamra-Mechemache, Z., Réquillart, V., Soregaroli, C., Trévisiol, A. (2008). Demand for dairy products in the EU. Food policy, 33(6), 644-656.

[5] Burton, M., Dorsett, R., Young, T. (1996). Changing preferences for meat: Evidence from UK household data, 1973-93. European Review of Agricultural Economics, 23(3), 357370 .

[6] Cragg, J. G. (1971). Some statistical models for limited dependent variables with application to the demand for durable goods. Econometrica: Journal of the Econometric Society, 829-844.

[7] Cupak, A., Pokrivcak, J.,Rizov, M. (2016). Demand for food away from home in Slovakia. Finance a úvěr: Czech Journal of Economics and Finance, 66(4), 354-369. 
[8] Davis, C., Blayney, D., Cooper, J.,Yen, S. (2009, August). An analysis of demand elasticity for fluid milk products in the US. In International Association of Agricultural Economists Meeting, August (pp. 16-22).

[9] De Alwis, A. E. N., Edirisinghe, J. C.,Athauda, A. M. T. P. (2011). Analysis of factors affecting fresh milk consumption among the mid-country consumers. Tropical agricultural research and extension, 12(2).

[10] Denver, S.,Jensen, J. D. (2014). Consumer preferences for organically and locally produced apples. Food Quality and Preference, 31, 129-134.

[11] Dong, D., Chung, C.,Kaiser, H. M. (2004). Modeling milk purchasing behavior with a panel data double-hurdle model. Applied Economics, 36(8), 769-779.

[12] Eakins, J. (2016). An application of the double hurdle model to petrol and diesel household expenditures in Ireland. Transport Policy, 47, 84-93.

[13] Euromonitor (2017). Drinking Milk Products in Slovakia, https://www.euromonitor.com/drinking-milk-products-in-slovakia/report on 16.10. 2018

[14] Eurostat (2017). Agricultural accounts and prices. Available online at: https://ec.europa.eu/eurostat/statistics-

explained/index.php?title=Agricultural_accounts_and_prices.

[15] Eurostat (2018). Milk and milk product statistics. Available online at: https://ec.europa.eu/eurostat/statistics-

explained/index.php/Milk_and_milk_product_statistics\#Milk_production

[16] Gao, X. M., Wailes, E. J.,Cramer, G. L. (1995). A microeconometric model analysis of US consumer demand for alcoholic beverages. Applied Economics, 27(1), 59-69.

[17] Garcia-German, S., Garrido, A.,Bardaji, I. (2014, August). Evaluating Transmission Prices between Global Agricultural Markets and Consumers' Food Price Indices in the EU. In 2014 International Congress, August (pp. 26-29).

[18] Gilbert, C. L.,Morgan, C. W. (2010). Food price volatility. Philosophical Transactions of the Royal Society of London B: Biological Sciences, 365(1554), 3023-3034.

[19] Goktolga, Z. G., Bal, S. G.,Karkacier, O. (2006). Factors effecting primary choice of consumers in food purchasing: The Turkey case. Food Control, 17(11), 884-889.

[20] Gould, B. W. (1996). Factors affecting US demand for reduced-fat fluid milk. Journal of Agricultural and Resource Economics, 68-81.

[21] Hatirli, S. A., Ozkan, B.,Aktas, A. R. (2004). Factors affecting fluid milk purchasing sources in Turkey. Food quality and preference, 15(6), 509-515.

[22] Heien, D. M.,Wessells, C. R. (1988). The demand for dairy products: structure, prediction, and decomposition. American Journal of Agricultural Economics, 70(2), 219228.

[23] Mabiso, A., Sterns, J., House, L.,Wysocki, A. (2005). Estimating Consumers' Willingness-to-pay for Country-of-origin Labels in Fresh Apples and Tomatoes: A Double-hurdle Probit Analysis of US Data Using Factor Scores (Doctoral dissertation, University of Florida).Newman, C., Henchion, M.,Matthews, A. (2003). A double-hurdle model of Irish household expenditure on prepared meals. Applied Economics, 35(9), 1053-1061.

[24] Mutlu, S.,Gracia, A. (2006). Spanish food expenditure away from home (FAFH): by type of meal. Applied Economics, 38(9), 1037-1047.

[25] Newman, C., Henchion, M., \& Matthews, A. (2003). A double-hurdle model of Irish household expenditure on prepared meals. Applied Economics, 35(9), 1053-1061.

[26] Sharpe, D. L., Abdel-Ghany, M., Kim, H. Y.,Hong, G. S. (2001). Alcohol consumption decisions in Korea. Journal of Family and Economic Issues, 22(1), 7-24.

[27] Sousa, J (2014): Estimation of price elasticity of demand for alcohol in the United Kingdom. HMRC Working Paper 16. 
[28] Swinnen, J., Van Berkum, S., Bozik, M., Blaas, G., Pokrivcak, J.,Banka, S. (2006). Market linkages in the Slovak agro-food sector.

[29] Tiryaki, G. Y.,Akbay, C. (2010). Consumers' fluid milk consumption behaviors in TURKEY: an application of multinomial logit model. QualityQuantity, 44(1), 87.

[30] Wan, W.,Hu, W. (2012, February). At Home Seafood Consumption in Kentucky: A double-hurdle model approach. In Southern Agricultural Economics Association Annual Meeting. Birmingham, AL.

[31] Yen, Steven T., and Andrew M. Jones. "Household consumption of cheese: an inverse hyperbolic sine double-hurdle model with dependent errors." American journal of agricultural economics 79.1 (1997): 246-251.

[32] Zhang, F., Huang, C. L., Lin, B. H., Epperson, J. E. (2008). Modeling fresh organic produce consumption with scanner data: a generalized double hurdle model approach. Agribusiness: An International Journal, 24(4), 510-522. 